Research Article

\title{
Catalytic Oxidation of Tartrazine in Aqueous Solution Using a Pillared Clay with Aluminum and Iron
}

\author{
Ángel David Gálvez-Serna1, Iván Fernando Macías-Quiroga1, Gloria Inés Giraldo-Gómez², \\ María Teresa Dávila-Arias ${ }^{1}$, Nancy Rocío Sanabria-González ${ }^{1, *}$ \\ ${ }^{1}$ Department of Chemical Engineering, Faculty of Engineering and Architecture, \\ Universidad Nacional de Colombia sede Manizales, Campus La Nubia, km 7 Vía al Aeropuerto, \\ AA 127 Manizales, Colombia. \\ ${ }^{2}$ Department of Physics and Chemical, Faculty of Exact and Natural Sciences, \\ Universidad Nacional de Colombia sede Manizales, Campus La Nubia, km 7 Vía al Aeropuerto, \\ AA 127 Manizales, Colombia.
}

Received: $2^{\text {nd }}$ January 2021; Revised: 25 th January 2021; Accepted: $26^{\text {th }}$ January 2021 Available online: 29th January 2021; Published regularly: March 2021

\section{Abstract}

In this work, pillared bentonite with $\mathrm{Al}-\mathrm{Fe}$ (Al-Fe-PILC) was synthesized and used as a heterogeneous Fentonlike catalyst in the oxidation of tartrazine azo-dye in aqueous solution. The modification of bentonite with the AlFe mixed system in a concentrated medium, with ultrasound assisted intercalation was carried out, and the obtained catalyst was characterized by XRF, XRD, and $\mathrm{N}_{2}$ adsorption at $77 \mathrm{~K}$. The oxidation of tartrazine with $\mathrm{Al}-\mathrm{Fe}-\mathrm{PILC}$, using different amounts of $\mathrm{H}_{2} \mathrm{O}_{2}$, expressed as a multiple (1, 3, 6, and 9) of a stoichiometry amount required to completely oxidize the dye was evaluated. The reaction of catalytic wet peroxide oxidation (CWPO) of the dye with $400 \mathrm{mg}$ of $\mathrm{Al}-\mathrm{Fe}-\mathrm{PILC}$ and 6 times the stoichiometric amount of $\mathrm{H}_{2} \mathrm{O}_{2}$ at $25{ }^{\circ} \mathrm{C}$, reached $98.2 \pm 1.8 \%$ of decolorization, $51.9 \pm 1.9 \%$ of TOC removal and $71.5 \pm 1.8 \%$ of TN removal. Results of this study show that the oxidation of tartrazine increased with the amount of $\mathrm{H}_{2} \mathrm{O}_{2}$ up to a certain limit. This oxidation process can be considered as an alternative for treating wastewater containing azo-dye because the reaction takes place under mild experimental conditions (room temperature and atmospheric pressure).

Copyright (C) 2021 by Authors, Published by BCREC Group. This is an open access article under the CC BY-SA License (https://creativecommons.org/licenses/by-sa/4.0).

Keywords: Pillared Clays; Al-Fe-PILC; tartrazine; decolorization; mineralization

How to Cite: Á.D. Gálvez-Serna, I.F. Macías-Quiroga, G.I. Giraldo-Gómez, M.T. Dávila-Arias, N.R. SanabriaGonzález. (2021). Catalytic Oxidation of Tartrazine in Aqueous Solution Using a Pillared Clay with Aluminum and Iron. Bulletin of Chemical Reaction Engineering \& Catalysis, 16(1), 76-87 (doi:10.9767/bcrec.16.1.9978.76-87)

Permalink/DOI: https://doi.org/10.9767/bcrec.16.1.9978.76-87

\section{Introduction}

The different sources of water pollution contain hazardous compounds which transfer adverse effects on the environment [1]. Some of the organic contaminants present in water

\footnotetext{
* Corresponding Author.

Email: nrsanabriag@unal.edu.co (N. Sanabria-González); Telp: +57-6-8879300
}

sources are synthetic dyes, which are used in various industries, including textile, leather, painting, printing, pharmaceutical, cosmetic and food processing [1-3]. Azo dyes make up for approximately $70 \%$ of all dyestuffs used worldwide [4], making them the largest group of synthetic colorants released into the environment $[5,6]$. Many dyes contain aromatic rings in their structures, which make them toxic, non- 
biodegradable, carcinogenic and mutagenic for aquatic systems and human health $[7,8]$.

Tartrazine (known as E102 or FDC Yellow 5) is a synthetic yellow azo-dye used primarily as a food coloring and also found in some pharmaceutical products and cosmetics $[9,10]$. This dye is found in much foodstuff as desserts, ice cream, soft drinks, confectionery, instant puddings, gelatin, sauces, etc. Food processing facilities require water for activities that include washing, processing, and clean-in-place operations. As a result, they generate a great amount of wastewater, which often contain very high levels of total suspended solids, chemical oxygen demand, fats, oils and dyes $[11,12]$. Dyes are visible to the human eye even in a low concentration $(<1 \mathrm{mg} / \mathrm{L})[13,14]$ and their inadequate disposal in aqueous ecosystems leads to reduction of sunlight penetration which in turn diminishes photosynthetic activity, resulting in acute toxic effects on the aquatic flora/fauna and dissolved oxygen concentration [15].

Different physical, chemical and biological treatment methods for dye removal have been adopted. These methods include adsorption, coagulation/flocculation, chemical oxidation (classical chemical treatments and advanced oxidation processes), electrochemical treatment and microbial or enzymatic degradation [6]. Advanced Oxidation Processes (AOPs) have been reported to be some of the most effective methods for the degradation of azo dyes, due to their complex chemical structure and recalcitrant nature (non-biodegradable) [16]. AOPs have been defined as water treatment processes which involve the generation of hydroxyl radicals (HO $)$ ) by chemical, photochemical and/or radiolytic methods. The hydroxyl radicals are very reactive species that attack most of the organic molecules and not only offer complete decolorization of aqueous solutions but also promise a considerable degree of mineralization and detoxification of the dyes and their oxidation/hydrolysis byproducts $[17,18]$.

Among the AOPs, the Fenton process $\left(\mathrm{H}_{2} \mathrm{O}_{2} / \mathrm{Fe}^{2+}\right)$ is one of the most effective methods of organic pollutant oxidation. Disadvantages in using the Fenton process include the production of a substantial amount of $\mathrm{Fe}(\mathrm{OH})_{3}$ sludge (precipitate) and additional water pollution caused by the homogeneous catalyst that added as an iron salt. To solve the previous drawback, a water-insoluble solid catalyst can be used. This heterogeneous Fenton process is called catalytic wet peroxide oxidation (CWPO) [1921]. The CWPO has been mainly used to oxidize phenols and their derivatives [20,22]. Its application in the degradation of other organic pollutants such dyes is not often reported [8,23-26]. The development of heterogeneous Fenton and Fenton-like catalysts has been extensively explored, using materials based on zeolites, clays and activated carbon loaded with iron and copper [24,27-30].

The pillaring procedure involves the formation, intercalation and subsequent fixation of polynuclear cations among clay layers. Thus, the lamellar spacing and specific area increase, making these materials attractive catalysts for various reactions [31]. Pillared clays with $\mathrm{Al}-\mathrm{Fe}$ (Al-Fe-PILC) are promising catalysts for the CWPO because they combine porous support with active sites capable of degrading organic compounds [32]. In the process of catalytic oxidation, the initial step is the adsorption of the dye upon the active support, which is the fundamental degradation mechanism [33]. The second step is the reaction between the adsorbed dye and $\mathrm{HO} \cdot$ radicals in the support surface. Thus, Al-Fe-PILC offers a combination of properties such as adsorption and catalytic activity, it is highly efficient for mineralization of pollutants [8,33]. In general, $\mathrm{Al}-\mathrm{Fe}$-PILCs have been shown to be efficient catalysts for phenol removal under mild conditions (atmospheric pressure and room temperature) without considerable leaching of metals [34,35]. Regarding the use of $\mathrm{Al}-\mathrm{Fe}-\mathrm{PILC}$ as catalysts for the CWPO of dyes (heterogeneous photo-Fenton oxidation is not included), there are reports just for acid chrome dark-blue $\left(\mathrm{C}_{16} \mathrm{H}_{9} \mathrm{O}_{9} \mathrm{Na}_{2} \mathrm{ClS}_{2} \mathrm{~N}_{2}\right)$ between 25 and $75{ }^{\circ} \mathrm{C}$ [26], tartrazine $\left(\mathrm{C}_{16} \mathrm{H}_{9} \mathrm{~N}_{4} \mathrm{Na}_{3} \mathrm{O}_{9} \mathrm{~S}_{2}\right)$ between 25 and $75{ }^{\circ} \mathrm{C}$ [23], orange acid II $\left(\mathrm{C}_{16} \mathrm{H}_{11} \mathrm{~N}_{2} \mathrm{NaO}_{4} \mathrm{~S}\right)$ at $60{ }^{\circ} \mathrm{C}$ [25], methyl orange $\left(\mathrm{C}_{14} \mathrm{H}_{14} \mathrm{~N}_{3} \mathrm{NaO}_{3} \mathrm{~S}\right)$ at $18 \pm 2.0{ }^{\circ} \mathrm{C} \quad$ [24] and Congo red $\left(\mathrm{C}_{32} \mathrm{H}_{22} \mathrm{~N}_{6} \mathrm{Na}_{2} \mathrm{O}_{6} \mathrm{~S}_{2}\right)$ at $25{ }^{\circ} \mathrm{C}$ [8].

In this work, pillared bentonite with $\mathrm{Al}-\mathrm{Fe}$ in a concentrated medium was synthesized (assisting the intercalation with ultrasound) [36], characterized and evaluated in the CWPO of tartrazine at $25^{\circ} \mathrm{C}$ and atmospheric pressure $(78 \mathrm{kPa})$. In addition to the degree of decolorization of tartrazine, the total organic carbon (TOC) and total nitrogen (TN) removals were also quantified, in relation to the amount of $\mathrm{H}_{2} \mathrm{O}_{2}$ used in the oxidation reaction.

\section{Materials and Methods}

\subsection{Reagent and Materials}

All the reagents used in the synthesis of the pillaring agent $\left(\mathrm{AlCl}_{3} .6 \mathrm{H}_{2} \mathrm{O}, \quad \mathrm{FeCl}_{3} .6 \mathrm{H}_{2} \mathrm{O}\right.$, $\mathrm{NaOH}, \mathrm{Na}_{2} \mathrm{SO}_{4}$, and $\mathrm{Ba}\left(\mathrm{NO}_{3}\right)_{2}$ ) were of analytical degree, obtained from Merck $\mathrm{KGaA}$ 
(Darmstadt, Germany) while $\mathrm{CaCl}_{2}, \mathrm{H}_{2} \mathrm{O}_{2}$ (30 wt\%) were obtained from Sigma-Aldrich (Saint Louis, MO, USA).

Tartrazine (azo food dye, molecular formula: $\mathrm{C}_{16} \mathrm{H}_{9} \mathrm{~N}_{4} \mathrm{Na}_{3} \mathrm{O}_{9} \mathrm{~S}_{2}, \quad 534.3 \mathrm{~g} / \mathrm{mol}$, CAS registry number: 1934-21-0) was a product of nonpurified industrial quality (purity 62\%, 38\% $\mathrm{NaCl}$ and $\mathrm{NaSO}_{4}$ combined), purchased from Retema S.A.S.-Colombia). The chemical structure of this dye is shown in Figure 1. Stock solution $(100 \mathrm{mg} / \mathrm{L})$ was made up by accurately dissolving a weighed quantity of the dye in double-distilled water. Experimental dye solution of different concentrations was prepared by diluting the stock solution with a suitable volume of double-distilled water.

\subsection{Synthesis and Characterization of Materi-} als

The starting material was a natural bentonite mined by Bentocol S.A. from Valle del Cauca (Colombia). This clay has been previously characterized, having found that dioctahedral smectite (or montmorillonite) is the main component of the natural material [24,37]. The bulk clay was ground in a ball mill, and clay powder passed through a 100 mesh. The particle size separation of the clay fraction $(<2 \mu \mathrm{m})$ was performed by gravitational sedimentation based on the Stokes' Law [38]. To achieve it, $100 \mathrm{~g}$ of the powder sample were suspended in $10 \mathrm{~L}$ of distilled water. The suspension was magnetically stirred for $20 \mathrm{~min}$, and transferred to a graduated cylinder for gravitational sedimentation. To obtain a fraction smaller than $2 \mu \mathrm{m}$, the suspension was allowed to rest for $16 \mathrm{~h}$, and the first $20 \mathrm{~cm}$ of the suspension removed. Subsequently, the suspension was centrifuged at $5000 \mathrm{rpm}$ for $10 \mathrm{~min}$ to recover the clay fraction, which was dried at $60{ }^{\circ} \mathrm{C}$, ground and sieved in a 100 mesh [39]. The clay fraction was homoionized with $0.5 \mathrm{M} \mathrm{CaCl}_{2}$, washed with distilled water until the leachate showed a negative test for chloride ions, dried at $60{ }^{\circ} \mathrm{C}$ and, finally, ground and sifted in an ASTM 100 mesh.

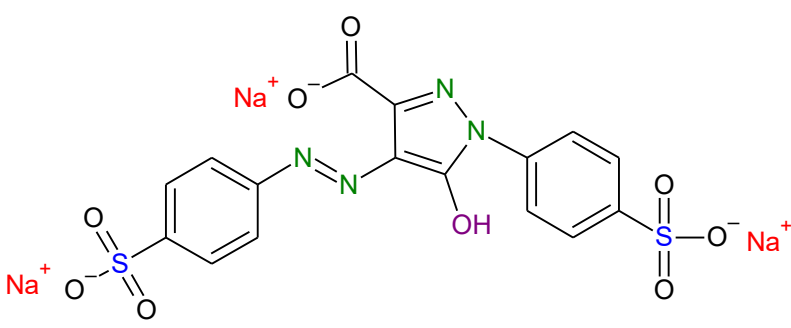

Figure 1. Chemical structure of tartrazine.
The pillaring agent of $\mathrm{Al}-\mathrm{Fe}$ purified $\left(\mathrm{Al}_{13}+\mathrm{Fe}\right.$ nitrate) was synthesized by using an $\mathrm{OH} /$ metal hydrolysis molar ratio of 2.4 , a previously published procedure [36]. The amount of Fe used in the synthesis of the pillaring agent was $5 \%$ molar because this amount favors the formation of larger and better-distributed pillars, which determines the good catalytic performance of these solids in the CWPO. For the modification, both homoionized clay fractions and the solid pillaring agent were mixed (20 meq of metal/g clay) and placed into a dialysis membrane, which was then immersed in distilled water and agitated for $3 \mathrm{~h}$. After that time, the mix underwent an ultrasound bath $(50 \mathrm{kHz})$ for $30 \mathrm{~min}$. The modified material was washed and centrifuged until reaching a conductivity close to that of distilled water, dried at $60{ }^{\circ} \mathrm{C}$, ground and sifted in an ASTM 100 mesh, and calcined for $2 \mathrm{~h}$ at $400{ }^{\circ} \mathrm{C}$ [36].

Both the clay fraction homoionized with calcium (labeled as Ca-Bent) and pillared clay with $\mathrm{Al}-\mathrm{Fe}$ (labeled as Al-Fe-PILC) were characterized by X-ray fluorescence (XRF), X-ray diffraction (XRD) and adsorption-desorption of $\mathrm{N}_{2}$ at $77 \mathrm{~K}$. XRF was performed using a Magix Pro Philips PW2440 instrument with samples prepared as glass pearls. For the X-ray diffraction, a Shimadzu LabX XRD-6000, which operates with $\mathrm{Cu}-\mathrm{K} \alpha$ radiation $(\lambda=1.5406 \AA$, steps of $0.02^{\circ} 2 \theta$ and 2 s/step) was used. Nitrogen adsorption-desorption isotherms were determined in a Micromeritics ASAP 2020 instrument at $77 \mathrm{~K}$ after outgassing the samples for $2 \mathrm{~h}$ at 90 ${ }^{\circ} \mathrm{C}$ followed by $3 \mathrm{~h}$ at $400{ }^{\circ} \mathrm{C}$. The specific surface area $\left(S_{\mathrm{BET}}\right)$ was measured by means of the BET equation and, the total pore volume, evaluated for nitrogen uptake at a relative pressure of 0.99. Microporous specific surface area and micropore volume were calculated using the $t$-method of the Harking-Jura equation [40].

\subsection{Measurement of Catalytic Activity}

Prior to the oxidation experiments, adsorption tests were performed for the tartrazine in aqueous solution. Adsorption of tartrazine on $\mathrm{Ca}$-Bent and $\mathrm{Al}-\mathrm{Fe}-\mathrm{PILC}$ in aqueous solution was determined by stirring $200 \mathrm{~mL}$ of the dye solution at an initial concentration of $25 \mathrm{mg} / \mathrm{L}$ with $400 \mathrm{mg}$ of solid material at a temperature of $25^{\circ} \mathrm{C}$, pH of 3.6 and $200 \mathrm{rpm}$ for different time intervals (every $30 \mathrm{~min}$ for $3 \mathrm{~h}$ ). The dye concentration, $\mathrm{Al}-\mathrm{Fe}-\mathrm{PILC}$ mass, temperature, $\mathrm{pH}$ and stirring conditions for the adsorption tests matched the same conditions in which the oxidation experiments were carried 
out, and were also established in accordance with literature data. The initial concentration of $25 \mathrm{mg} / \mathrm{L}$ is in the range of azo dyes' concentrations, usually found in industrial waste streams (between 10 and $50 \mathrm{mg} / \mathrm{L}$ ) [41,42]. In Fenton-like reactions of phenol and dye oxidation with $\mathrm{Al}-\mathrm{Fe}-\mathrm{PILC}$, the $\mathrm{pH}$ is sustained between 3.5 and $4.0[24,43]$, and the optimal value reported in the literature has been 3.7 $[24,44,45]$. The average catalyst load reported for chemical oxidation of azo dyes varies between $2-5 \mathrm{~g} / \mathrm{L}[24,26,41]$, so the lowest dose was used for this study. Stirring speeds of 200 rpm guarantee a complete mixing of the solid (adsorbent or catalyst) in the solution [24].

The oxidation reaction with a powdered catalyst was performed in a batch glass reactor, open to the atmosphere, thermostated at $25^{\circ} \mathrm{C}$, under constant magnetic stirring at $200 \mathrm{rpm}$. For each test, the reactor was loaded with 200 $\mathrm{mL}$ of aqueous solution at $25 \mathrm{mg} / \mathrm{L}$ and $400 \mathrm{mg}$ of the catalyst. In this study, the $\mathrm{pH}$ of the medium was adjusted to 3.6 by using diluted 0.1 $\mathrm{M} \mathrm{H}_{2} \mathrm{SO}_{4}$ acid or $0.1 \mathrm{M} \mathrm{NaOH}$. Once the adsorption equilibrium time was reached, $8 \mathrm{~mL}$ of an $\mathrm{H}_{2} \mathrm{O}_{2}$ solution $(2.0 \mathrm{~mL} / \mathrm{h})$ was added to the reactor. Although the addition of the total $\mathrm{H}_{2} \mathrm{O}_{2}$ dose is frequent at the beginning of the reaction, the gradual peroxide dosing had positive effects on the increase of TOC removal [46]. The time of reaction was $5 \mathrm{~h}$ (not including the time of dye adsorption-desorption equilibrium). The amount of $\mathrm{H}_{2} \mathrm{O}_{2}$ was varied in multiples of stoichiometry amount (1, 3, 6, and 9), which is theoretically required to completely oxidize one mole of tartrazine into $\mathrm{CO}_{2}, \mathrm{H}_{2} \mathrm{O}$, and mineral acids, according to Equation (1):

$$
\begin{array}{r}
\mathrm{C}_{16} \mathrm{H}_{9} \mathrm{~N}_{4} \mathrm{O}_{9} \mathrm{~S}_{2} 2^{3-}+45 \mathrm{H}_{2} \mathrm{O}_{2}==>16 \mathrm{CO}_{2}+ \\
47 \mathrm{H}_{2} \mathrm{O}+4 \mathrm{NO}_{3}+2 \mathrm{SO}_{4}{ }^{2-}+5 \mathrm{H}^{+}
\end{array}
$$

Dye decolorization (dye removal efficiency) of tartrazine was measured by monitoring the absorbance of dye in the aqueous medium at its respective maximum absorption wavelength $\left(\lambda_{\max }=429 \mathrm{~nm}\right)$ using a UV-Vis spectrophotometer (Mapada V-1200, China). The dye concentration was determined from aliquots $(1 \mathrm{~mL}$ of sample filtered in $0.45 \mu \mathrm{m}$ millipore paper) measured at time intervals and by using a calibration curve relating absorbance vs. sample concentration. The concentration interval went from 0.5 to $20 \mathrm{mg} / \mathrm{L}$, with a correlation coefficient $\left(\mathrm{R}^{2}\right)$ of 0.9919 . Detection limit (DL) and quantification limit (QL) were $0.21 \mathrm{mg} / \mathrm{L}$ and $0.53 \mathrm{mg} / \mathrm{L}$, respectively.

The dye decolorization was calculated from the following Equation (2):

$$
\text { Decolorization }(\%)=\frac{C_{0}-C_{t}}{C_{0}} \times 100
$$

where $C_{0}$ is the dye concentration at time zero $(t=0)$. This concentration corresponds to the solution in the adsorption-desorption equilibri$\mathrm{um}$, and $C_{\mathrm{t}}$ is the dye concentration at time $t$.

Kinetic studies were performed by monitoring the change in the tartrazine concentration $\left(C_{t} / C_{0}\right)$ as a function of time $(t)$. Apparent firstorder rate constants $\left(k_{\text {app }}\right)$ for the different amounts of $\mathrm{H}_{2} \mathrm{O}_{2}$ were determined from the plot of $-\ln \left(C_{t} / C_{0}\right)$ versus time $(t)$; and the $k_{\text {app }}$ was calculated with the slope of the line obtained [47].

The contents of the total organic carbon (TOC) and total nitrogen (TN) at the beginning and end of the reaction were determined in filtered aliquots of the reaction mixture using a TOC/TN analyzer (Multi N/C 3100, Analytik Jena AG, Germany). The Fe ions leaching from the catalyst at the end of the reaction were measured using an atomic absorption spectrophotometer (Thermo Scientific iCE 3000 Series). All of the oxidation tests were performed by triplicate.

\section{Results and Discussions}

\subsection{Characterization of Materials}

Table 1 shows the chemical analysis of starting bentonite and $\mathrm{Al}-\mathrm{Fe}-\mathrm{PILC}$. A recent study proposes the use of a practical chart to identify the predominant clay mineral based on oxide composition in clay soils [48]. In accordance with the chemical composition of $\mathrm{SiO}_{2}$ (56.79 wt\%), $\mathrm{Al}_{2} \mathrm{O}_{3}+\mathrm{Fe}_{2} \mathrm{O}_{3},(27.67 \mathrm{wt} \%)$, the sample of calcium bentonite was located in the montmorillonite zone. Clay modified with $\mathrm{Al}-\mathrm{Fe}$ showed an increase in the content of

Table 1. Chemical analysis (wt\%), mass ratios of $\mathrm{Si} / \mathrm{Al}$ and $\mathrm{Si} / \mathrm{Fe}$ of calcium bentonite and pillared clay with $\mathrm{Al}-\mathrm{Fe}$.

\begin{tabular}{lcccccccc}
\hline Sample & $\mathrm{SiO}_{2}$ & $\mathrm{Al}_{2} \mathrm{O}_{3}$ & $\mathrm{Fe}_{2} \mathrm{O}_{3}$ & $\mathrm{MgO}$ & $\mathrm{CaO}$ & $\mathrm{Na}_{2} \mathrm{O}$ & $\mathrm{Si} / \mathrm{Al}$ & $\mathrm{Si} / \mathrm{Fe}$ \\
\hline Ca-Bent & 56.79 & 20.82 & 6.85 & 3.25 & 2.23 & 0.85 & 2.41 & 5.54 \\
Al-Fe-PILC & 52.44 & 26.54 & 6.25 & 3.10 & 1.21 & 0.69 & 1.76 & 5.61 \\
\hline
\end{tabular}


$\mathrm{Al}_{2} \mathrm{O}_{3}$ and thus a decrease in the $\mathrm{Si} / \mathrm{Al}$ ratio respect to $\mathrm{Ca}$-Bent. Although the content of $\mathrm{Fe}_{2} \mathrm{O}_{3}$ decreased in $\mathrm{Al}-\mathrm{Fe}-\mathrm{PILC}$ with respect to $\mathrm{Ca}$ Bent, the $\mathrm{Si} / \mathrm{Fe}$ ratio increased slightly. This last result can be associated with the uncertainty of the measurement made by XRF. Given the conditions of the synthesis of the solid pillaring agent and the low incorporation of $\mathrm{Fe}$ [36], this result appears reasonable. The above happened since the introduction of aluminum is very high in the pillared clay compared to iron, making the proportion of $\mathrm{Fe}_{2} \mathrm{O}_{3}$ less important.

Powder X-ray diffraction patterns of the calcium bentonite and pillared clay with $\mathrm{Al}-\mathrm{Fe}$ are shown in Figure 2. The shift in $d_{001}$ reflection for the basal spacing of $13.5 \AA\left(2 \theta=6.52^{\circ}\right)$ for the $\mathrm{Ca}$-Bent to higher values in Al-Fe-PILC $\left(18.5 \AA, 2 \theta=4.77^{\circ}\right)$ confirms the effective introduction of metal polyhydroxocations and the subsequent formation of pillars in the interlaminar spacing. The dimensions of an $\mathrm{Al}_{13}$ Keggin ion have been estimated to be 1:09 $\mathrm{nm} \times 0: 98$ $\mathrm{nm} \times 0: 97 \mathrm{~nm}[49,50]$. After heating with air at $500{ }^{\circ} \mathrm{C}$, Keggin ions lost their water ligands forming shorter $\mathrm{Al}_{13}$-blocks, with a height of $0.84 \mathrm{~nm}$, becoming the structure supporting pillars [50]. The basal spacing of $18.5 \AA$ for $\mathrm{Al}-\mathrm{Fe}-\mathrm{PILC}$ corresponded to the thickness of a montmorillonite-type clay sheet $(\sim 10 \AA)$ plus the aluminum pillar $(8.4 \AA)$. The amount of iron incorporated in the solid pillarizing agent was very small $(0.17 \mathrm{wt} \%)$ and did not contribute to the formation of $\mathrm{Fe}_{2} \mathrm{O}_{3}$ pillars. The iron incorporated in the pillaring agent was decorating the alumina pillars and not as iron oxide on the sheets of clay (cluster) [36].

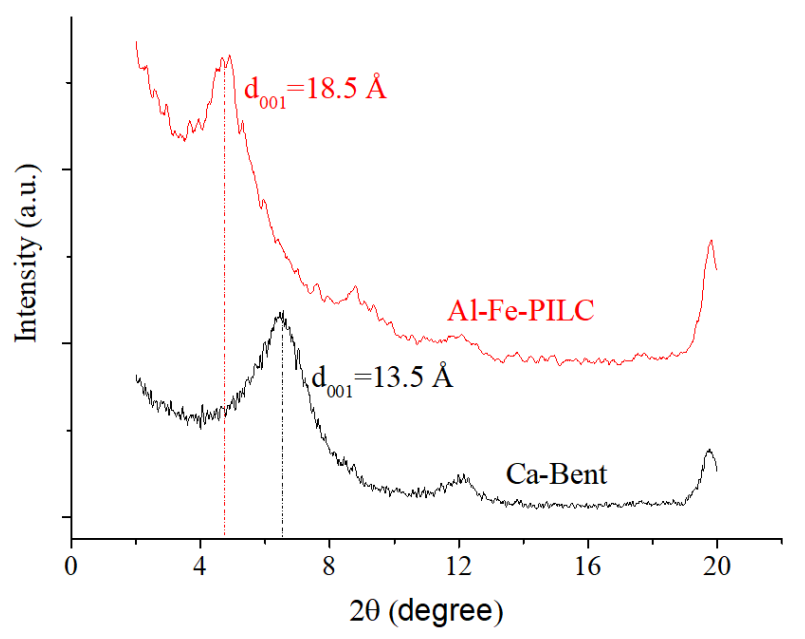

Figure 2. X-ray diffraction patterns of calcium bentonite and pillared clay with $\mathrm{Al}-\mathrm{Fe}$.
Adsorption-desorption isotherms of Ca-Bent and $\mathrm{Al}-\mathrm{Fe}-\mathrm{PILC}$ are shown in Figure 3. There is an increase in the adsorption capacity of $\mathrm{N}_{2}$ due to the modification of the clay by pillaring. According to the IUPAC classification [51], CaBent presented an isotherm type IVa while AlFe-PILC is a combination of types Ia and IVa, both with H3 hysteresis loop. Type IVa isotherms are characteristics of mesoporous adsorbents. The H3 hysteresis loop is the result of non-rigid aggregates of plate-like particles. The adsorption isotherm of $\mathrm{Al}-\mathrm{Fe}-\mathrm{PILC}$ between 0.05 and 0.2 of relative pressure has the shape of a type Ia isotherm, characteristic of microporous materials. Thus, the combination of isotherms type Ia and IVa with H3 hysteresis loop indicates that both slit-like mesopores and micropores are formed.

The specific surface area (SSA) was 41.8 $\mathrm{m}^{2} / \mathrm{g}$ and $150.3 \mathrm{~m}^{2} / \mathrm{g}$ for Ca-Bent and $\mathrm{Al}-\mathrm{Fe}-\mathrm{PILC}$, respectively. The pore volume at $p / p o=0.99$ is of $0.0605 \mathrm{~cm}^{3} / \mathrm{g}$ for Ca-Bent and $0.1093 \mathrm{~cm}^{3} / \mathrm{g}$ for Al-Fe-PILC. The $t$-plot method was used to determine the specific area and the volume developed by micropores of the samples. These values are $2.2 \mathrm{~m}^{2} / \mathrm{g}$ and 0.0008 $\mathrm{cm}^{3} / \mathrm{g}$ for Ca-Bent and $107.0 \mathrm{~m}^{2} / \mathrm{g}$ and 0.0414 $\mathrm{cm}^{3} / \mathrm{g}$ for $\mathrm{Al}-\mathrm{Fe}-\mathrm{PILC}$, respectively. The specific surface area of Ca-Bent is fundamentally the external surface (approx. 95\% of SSA), characteristic of a structure of closed sheets, attributed to the heterogeneous arrangement of the aluminosilicate sheets. For Al-Fe-PILC, the specific surface area is basically microporous (approx. 71\% of SSA), which is a typical feature of pillared clays [8,24].

The above results (XRF, XRD, and $\mathrm{N}_{2}$ sortometry) are similar to those found in the

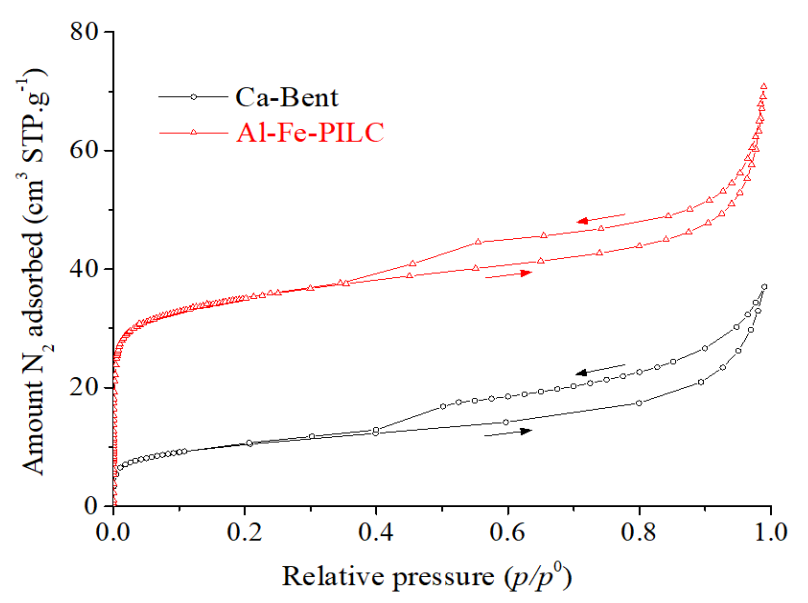

Figure 3. Nitrogen adsorption-desorption isotherms of calcium bentonite and pillared clay with $\mathrm{Al}-\mathrm{Fe}$. 
literature for the same system (pillared bentonite with $\mathrm{Al}-\mathrm{Fe}$ in concentrated medium, intercalation assisted with ultrasound), indicating that the synthesis methodology of pillared bentonite was reproducible [36].

\subsection{Catalytic Activity of Al-Fe-PILC}

Prior to the CWPO tests, adsorption tests of tartrazine on the materials were carried out. The maximum adsorption occurred during the first 30 minutes and stabilized after $1 \mathrm{~h}$, reaching values of $4.1 \pm 0.2$ and $12.5 \pm 0.5 \%$ for $\mathrm{Ca}$ Bent and $\mathrm{Al}-\mathrm{Fe}-\mathrm{PILC}$, respectively. The low adsorption of the dye in Ca-Bent was due to the fact that tartrazine is an anionic dye and, bentonite, a 2:1 layered silicate with a negative charge due to ionic substitution in its structure $[52,53]$. This charge in Ca-Bent is balanced by cations $\mathrm{Ca}^{2+}$ present in the interlayer space, which cannot be interchanged by the anionic species of the colorant in solution $\left(\mathrm{C}_{16} \mathrm{H}_{9} \mathrm{~N}_{4} \mathrm{O}_{9} \mathrm{~S}_{2}{ }^{3-}\right)$. Pillared clays are materials which have lower hydrophilicity than their parent clays $[8,54]$. It has been established that pillaring improves the efficiency in processes of adsorption of the anionic dye [55], therefore its greater adsorption capacity of tartrazine in an aqueous medium.

For all the oxidation tests, an adsorption time of $1 \mathrm{~h}$ was established, guaranteeing conditions of adsorption-desorption equilibrium. The catalytic activity of calcium bentonite and pillared bentonite with $\mathrm{Al}-\mathrm{Fe}$ in the oxidation of tartrazine is shown in Figure 4. For the reaction blank (only $6 \mathrm{H}_{2} \mathrm{O}_{2}$ ), Ca-Bent $+6 \mathrm{H}_{2} \mathrm{O}_{2}$ and

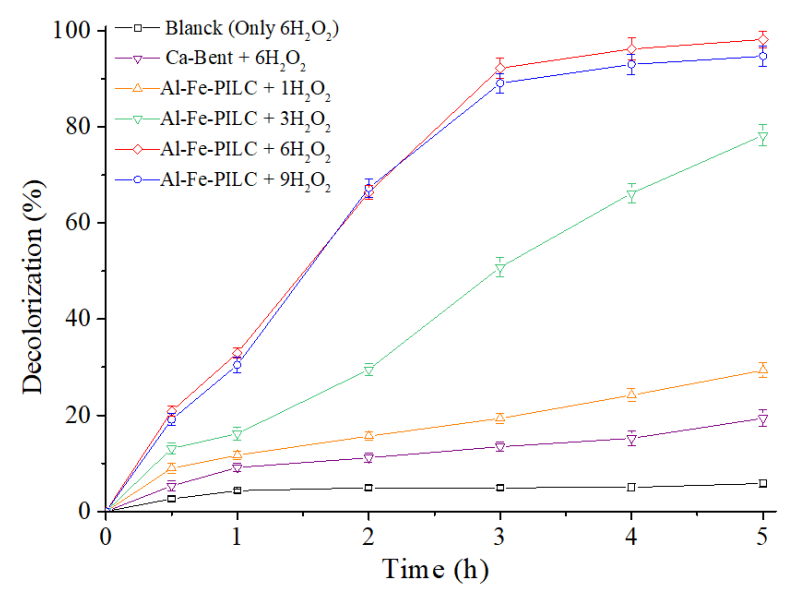

Figure 4. Effect of $\mathrm{H}_{2} \mathrm{O}_{2}$ amount in tartrazine removal. Test conditions: $25 \mathrm{mg} / \mathrm{L}$ dye concentration, $\mathrm{pH} 3.6,400 \mathrm{mg}$ of catalyst and $25^{\circ} \mathrm{C}$. The amount of $\mathrm{H}_{2} \mathrm{O}_{2}(1,3,6$, and 9) was varied in multiples of stoichiometry amount required to completely oxidize the dye.
$\mathrm{Al}-\mathrm{Fe}-\mathrm{PILC}+1 \mathrm{H}_{2} \mathrm{O}_{2}$, decolorization shows a slight increase as a function of the reaction time. The color removal of $\mathrm{Al}-\mathrm{Fe}-\mathrm{PILC}+$ $3 \mathrm{H}_{2} \mathrm{O}_{2}$ in the first $2 \mathrm{~h}$ of reaction increased slightly, and then at a higher speed (between 2 and $5 \mathrm{~h}$ ). $\mathrm{Al}-\mathrm{Fe}-\mathrm{PILC}$ (with 6 and $9 \mathrm{H}_{2} \mathrm{O}_{2}$ ) evidenced a decolorization curve with two zones, one of increase in color removal (during the first $3 \mathrm{~h}$ of reaction) and then a stabilization zone (between 3 and $5 \mathrm{~h}$ ).

Decolorization achieved with only $\mathrm{H}_{2} \mathrm{O}_{2}$ (blank, equivalent to 6 times the stoichiometric amount, without catalyst) was $5.81 \pm 0.79 \%$. The unmodified clay (Ca-Bent) with 6 times the stoichiometric of $\mathrm{H}_{2} \mathrm{O}_{2}$ amount showed a low activity, reaching color elimination close to $19.4 \pm 1.7 \%$. This catalytic activity can be related to the iron content of the raw clay mineral (6.85 wt $\% \mathrm{Fe}_{2} \mathrm{O}_{3}$, Table 1). Catalytic activity of the pillared bentonite with $\mathrm{Al}-\mathrm{Fe}$ was increased with respect to the starting clay and varied with the dose of $\mathrm{H}_{2} \mathrm{O}_{2}$ used in the reaction. Although the amount of iron incorporated into $\mathrm{Al}-\mathrm{Fe}-\mathrm{PILC}$ was very low compared to the iron content of $\mathrm{Ca}$-Bent, the results indicate that $\mathrm{Fe}$ incorporated by pillaring is more active than that originally present in the clay, results similar to those reported in the literature [24,35].

The oxidation reaction of tartrazine carried out with a dose of $\mathrm{H}_{2} \mathrm{O}_{2}$ of 1 and 3 times the stoichiometric amount reached a decolorization of $29.4 \pm 1.6$ and $78.3 \pm 2.3 \%$, respectively. When the stoichiometric amount of $\mathrm{H}_{2} \mathrm{O}_{2}$ was increased to 6 and 9 times, the decolorization obtained after $5 \mathrm{~h}$ of reaction decreased from

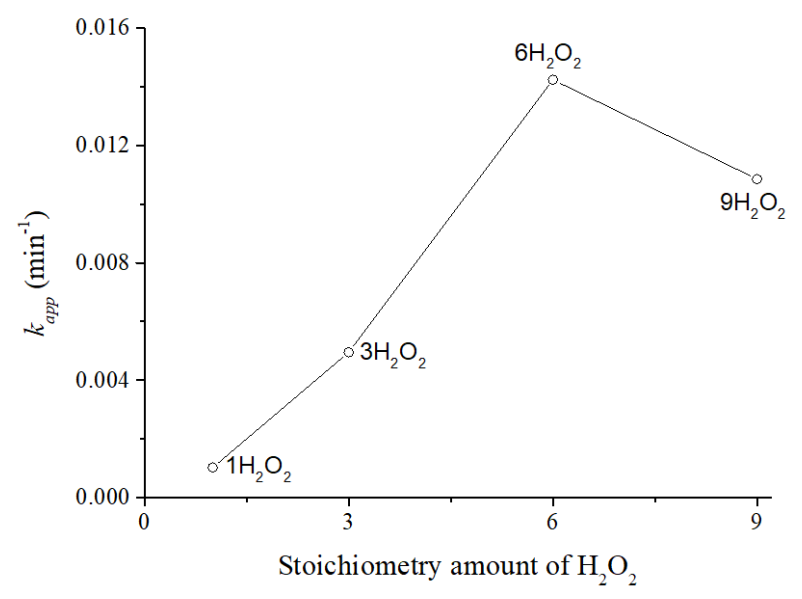

Figure 5. Tartrazine decolorization rate constant ( $k_{\text {app }}$ ) versus the $\mathrm{H}_{2} \mathrm{O}_{2}$ amount. Test conditions: $25 \mathrm{mg} / \mathrm{L}$ dye concentration, $\mathrm{pH} 3.6,400 \mathrm{mg}$ of catalyst and $25{ }^{\circ} \mathrm{C}$. The amount of $\mathrm{H}_{2} \mathrm{O}_{2}(1,3$, 6 , and 9) varied in multiples of stoichiometry amount required to completely oxidize the dye. 
$98.2 \pm 1.8$ to $94.7 \pm 2.1 \%$. Excess $\mathrm{H}_{2} \mathrm{O}_{2}$ in a reaction medium (9 times the stoichiometric amount in this investigation) increased the chance for recombination of the radicals (i.e., scavenging effect) and production of less active radicals such as $\mathrm{HO}_{2}$ - in the solution to generate inactive species as $\mathrm{H}_{2} \mathrm{O}$ and $\mathrm{O}_{2}$, which can be expressed by the reactions described by Equations (3) and (4) [20,46,56]:

$$
\begin{aligned}
& \mathrm{H}_{2} \mathrm{O}_{2}+\cdot \mathrm{OH} \rightarrow \mathrm{H}_{2} \mathrm{O}+\mathrm{HO}_{2} \bullet \\
& \mathrm{HO}_{2} \cdot+\cdot \mathrm{OH} \rightarrow \mathrm{H}_{2} \mathrm{O}+\mathrm{O}_{2}
\end{aligned}
$$

Data of change in the tartrazine concentration $\left(C_{t} / C_{0}\right)$ as a function of time $(t)$ were adjusted to first-order kinetics and $k_{\text {app }}$ values, for each amount of $\mathrm{H}_{2} \mathrm{O}_{2}$. For the four quantities of $\mathrm{H}_{2} \mathrm{O}_{2}$ used in the CWPO of tartrazine, the coefficient of determination $\left(\mathrm{R}^{2}\right)$ was higher than 0.965, confirming that data fit the first order model. Figure 5 shows the effect of $\mathrm{H}_{2} \mathrm{O}_{2}$ on the rate constant of decolorization $\left(k_{\text {app }}\right)$ of tartrazine in aqueous solution. When the amount of $\mathrm{H}_{2} \mathrm{O}_{2}$ is increased from 1 to 3 times the stoichiometric value, $k_{\text {app }}$ value increased 4.9 times. Additions of 6 times the stoichiometric amount of $\mathrm{H}_{2} \mathrm{O}_{2}$ increased $k_{\text {app }} 14$ times compared to the value obtained with 1 time of stoichiometric $\mathrm{H}_{2} \mathrm{O}_{2}$. Finally, the amount of $\mathrm{H}_{2} \mathrm{O}_{2}$ was 9 times the stoichiometric value, $k_{\text {app }}$ decreased by $23.8 \%$ in relation to the value obtained with 6 times the stoichiometric $\mathrm{H}_{2} \mathrm{O}_{2}$. A similar behavior, that is, the existence of an optimum hydrogen peroxide dose has been found during photoFenton degradation of the reactive brilliant orange over iron-pillared montmorillonite. When increasing the amount of $\mathrm{H}_{2} \mathrm{O}_{2}$ from 2.9 to 9.8 $\mathrm{mmol} / \mathrm{L}$, degradation efficiency of the dye went up from 65.4 to $95.6 \%$ at $90 \mathrm{~min}$. However, when the $\mathrm{H}_{2} \mathrm{O}_{2}$ dosage was $19.6 \mathrm{mmol} / \mathrm{L}$, the removal of dye decreased [57]. In general, an excess of $\mathrm{H}_{2} \mathrm{O}_{2}$ is used with respect to the theoretical $\left[\mathrm{H}_{2} \mathrm{O}_{2}\right] /[$ organic compound] molar ratio to reach the maximum degradation of organic compound $[46,58]$.

UV-Vis spectra of tartrazine oxidation using $\mathrm{Al}-\mathrm{Fe}-\mathrm{PILC}$ and 6 times the stoichiometric amount of $\mathrm{H}_{2} \mathrm{O}_{2}$ are shown in Figure 6. At $2 \mathrm{~h}$ of reaction, a considerable decrease in the absorbance at $429 \mathrm{~nm}$ is observed (close to $67 \%$ of decolorization) and after $3 \mathrm{~h}$ of reaction, the color removal is greater than $92 \%$ so the yellow tone of the solution no longer it is noticeable to the naked eye.

There is no criterion for determining the amount of hydrogen peroxide necessary for the oxidation of an azo dye since it depends on the structure of the compound and the reaction temperature. An excess of $\mathrm{H}_{2} \mathrm{O}_{2}$ is usually used with respect to the stoichiometric amount. For example, for the oxidation of tartrazine (50 $\mathrm{mg} / \mathrm{L}$ ) with $\mathrm{Al}, \mathrm{Fe}$-pillared clay ( $0.5 \mathrm{~g}$ of solid catalyst in $100 \mathrm{~mL}$ of aqueous solution of dye), a dose of $\mathrm{H}_{2} \mathrm{O}_{2}$ equal to 9.3 times the stoichiometric amount was used. Tartrazine removal at $4 \mathrm{~h}$ of reaction at $75{ }^{\circ} \mathrm{C}$ reached about $97.5 \%$ [23]. For the oxidation of methyl orange (100 $\mathrm{mg} / \mathrm{L}$ ) with $\mathrm{Al} / \mathrm{Fe}-\mathrm{PILCs}$, the dose of $\mathrm{H}_{2} \mathrm{O}_{2}$ was 0.9 times the stoichiometric amount. Removal of the dye was close to $80 \%$ in only $1 \mathrm{~h}$ of reaction at $18 \pm 2.0^{\circ} \mathrm{C}$ [24]. However, in two previous investigations, the TOC removal was not quantified. Methyl orange is an excellent model chemical molecule for the catalytic assessment of active solids in Fenton-like reactions, as, for instance, CWPO [24]. Nevertheless, it is an azo dye of simple structure, of low molecular weight (327.33 g/mol, topological polar surface
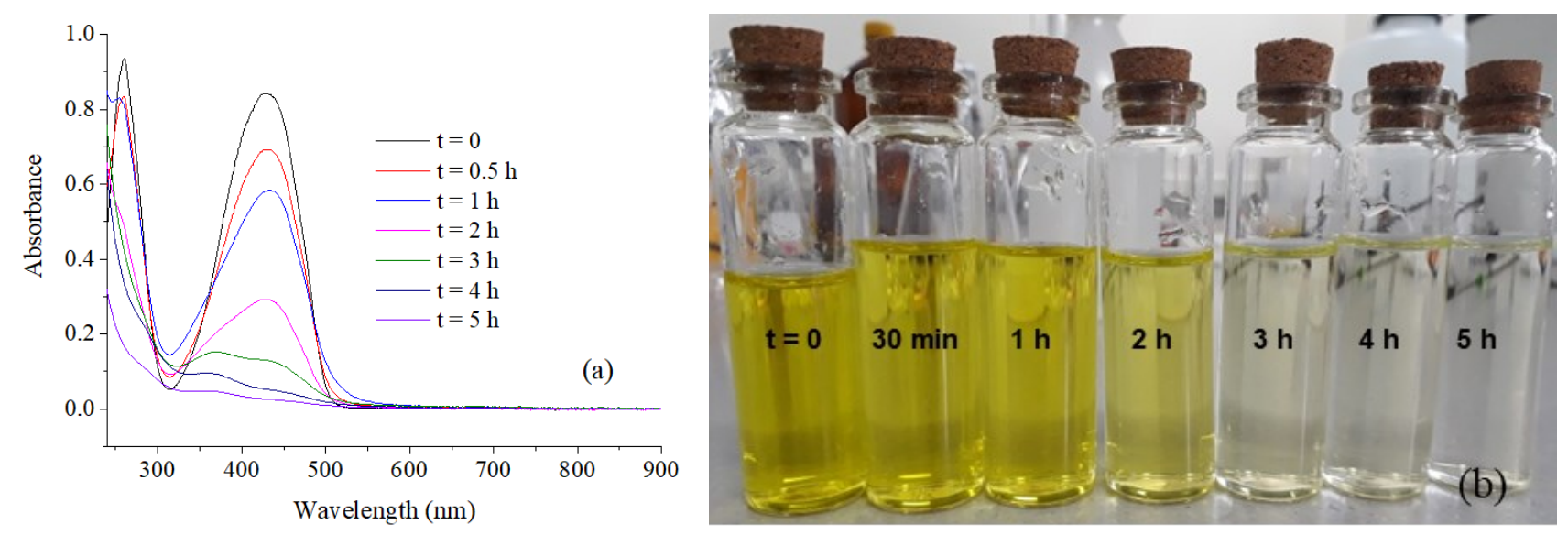

Figure 6. (a) UV-Vis spectra of tartrazine oxidation using Al-Fe-PILC as a function of the reaction time and (b) appearance of the solutions. Test conditions: $25 \mathrm{mg} / \mathrm{L}$ dye concentration, $\mathrm{pH} 3.6,400 \mathrm{mg}$ of catalyst, $25^{\circ} \mathrm{C}$ and 6 times the stoichiometric amount of $\mathrm{H}_{2} \mathrm{O}_{2}$. 
area of $93.5 \mathrm{~A}^{2}$ ), in comparison with tartrazine (534.36 $\mathrm{g} / \mathrm{mol}$, a topological polar surface area of $229 \mathrm{~A}^{2}$ ). These differences in the two monoazo dyes, as well as in the reaction by-products, mean that the results for similar catalysts are not comparable.

TOC and TN removal efficiency in the oxidation of tartrazine using Ca-Bent and $\mathrm{Al}-\mathrm{Fe}-\mathrm{PILC}$ is shown in Figure 7. The $\mathrm{H}_{2} \mathrm{O}_{2}$ only (6 times the stoichiometric amount, without catalyst) achieves very low removal of TOC and TN. When the Al-Fe-PILC catalyst is used and the $\mathrm{H}_{2} \mathrm{O}_{2}$ dose is increased from 1 to 6 times the stoichiometric amount, the removal of TOC and TN increases considerably. By increasing the dose of $\mathrm{H}_{2} \mathrm{O}_{2}$ (9 times the stoichiometric amount), the removal of TOC and TN decrease with respect to the reaction with fewer $\mathrm{H}_{2} \mathrm{O}_{2}$ (6 times the stoichiometric amount). In all tartrazine oxidation tests, it was found that TN removal was greater than TOC, reaching TN conversion of up to $71.5 \pm 1.8 \%$ (with 6 times the stoichiometric amount of $\mathrm{H}_{2} \mathrm{O}_{2}$ ). Similar results for the oxidation of Congo red were obtained with $\mathrm{Al}-\mathrm{Fe}-\mathrm{PILC}$. At $4 \mathrm{~h}$ of treatment, $\mathrm{NO}_{3-}$ concentration (measured by ion chromatography) was practically zero, demonstrating that the catalyst gives a major loss of the initial nitrogen as volatile $\mathrm{N}$-compounds, probably $\mathrm{N}_{\mathrm{x}} \mathrm{O}_{\mathrm{y}}$ and $\mathrm{N}_{2}$ or $\mathrm{NH}_{4}{ }^{+}$[8]. The influence of the $\mathrm{H}_{2} \mathrm{O}_{2}$ dose on the TOC or TN removal (Figure 7) was similar to that obtained for decolorization (Figure 4), with an optimum oxidant concentration. For an $\mathrm{H}_{2} \mathrm{O}_{2}$ dose above that value,

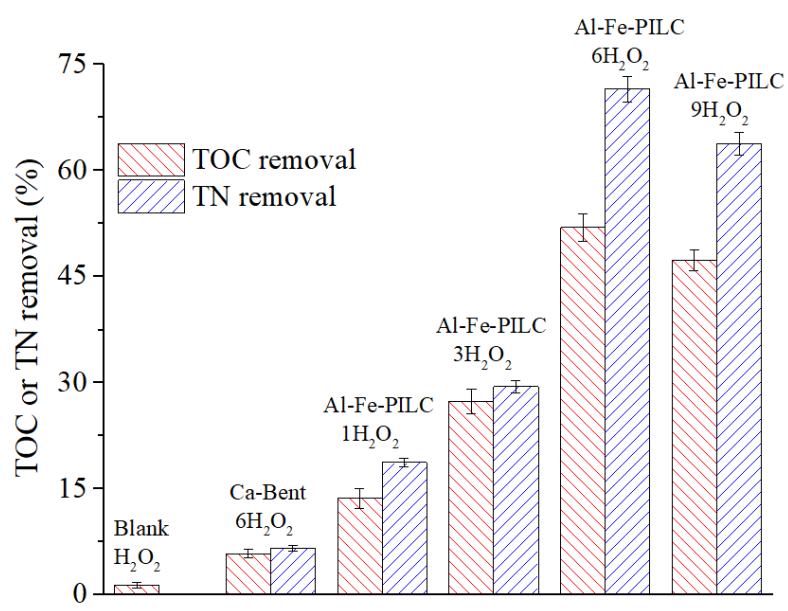

Figure 7. Total organic carbon (TOC) and total nitrogen (TN) removals at the end of the reaction. Test conditions: $25 \mathrm{mg} / \mathrm{L}$ dye concentration, $\mathrm{pH} 3.6,400 \mathrm{mg}$ of catalyst and $25^{\circ} \mathrm{C}$. The amount of $\mathrm{H}_{2} \mathrm{O}_{2}(1,3,6$, and 9) varied in multiples of stoichiometry amount required to completely oxidize the dye. the final TOC or TN removals decreased a little, an effect similar to those reported by other researchers [59-61].

The reaction path for the generation of reactive species and mineralization of dye using $\mathrm{Al}-\mathrm{Fe}-\mathrm{PILC}$ starts by reduction of $\mathrm{Fe}^{3+}$ on the surface of $\mathrm{Al}-\mathrm{Fe}$-PILC to $\mathrm{Fe}^{2+}$. Then the $\mathrm{Fe}^{2+}$ formed accelerates the decomposition of $\mathrm{H}_{2} \mathrm{O}_{2}$ in solution (Fenton reagent), generating hydroxyl $(\mathrm{HO} \cdot)$ and hydroperoxyl $\left(\mathrm{HO}_{2} \bullet\right)$ radicals. These radicals attack the dye molecule leading to reaction intermediates and, finally, the reaction intermediates are mineralized into $\mathrm{CO}_{2}, \mathrm{H}_{2} \mathrm{O}, \mathrm{NO}_{3}{ }^{-}$and $\mathrm{SO}_{4}{ }^{2-}$. The simplified reactions that schematize this process are shown in Equations (5) and (6) [8]:

$\mathrm{Fe}^{3+} / \mathrm{PILC}+\mathrm{H}_{2} \mathrm{O}_{2} \rightarrow \mathrm{Fe}^{2+} / \mathrm{PILC}+\mathrm{HO}_{2} \cdot+\mathrm{H}^{+}$ $\mathrm{Fe}^{2+} / \mathrm{PILC}+\mathrm{H}_{2} \mathrm{O}_{2} \rightarrow \mathrm{Fe}^{3+} / \mathrm{PILC}+\mathrm{HO} \cdot+\mathrm{OH}^{-}$

When the $\mathrm{HO} \cdot$ and $\mathrm{HO}_{2}$ - radicals formed during the reactions attack the azo group $(-\mathrm{N}=\mathrm{N}-)$ and break it, there is a color decay of the solution, which is used to measure the efficiency of the catalytic oxidation of the azo dye [24]. In this study, the oxidation by-products of tartrazine (other than $\mathrm{CO}_{2}$ and $\mathrm{NOx}$ ) were not quantified by chromatographic techniques. In solutions of tartrazines pre-treated by electrocoagulation (EC) and, subsequently, by advanced oxidation by photoelectro-Fenton (PEF), 18 compounds have been identified by GC-MS. The dehydroxylated by-products (in the form of phenols and quinones) are the intermediates formed by the action of $\mathrm{HO} \cdot$ radicals, as well as by aliphatic carboxylic acids (cannot be mineralized) [62].

In the CWPO process, the concentration of oxidant $\left(\mathrm{H}_{2} \mathrm{O}_{2}\right)$ is a vital factor that considerably affects the removal of organic pollutants. The amount of generated hydroxyl radicals is directly related to the concentration of $\mathrm{H}_{2} \mathrm{O}_{2}$ [20]. According to the results of the catalytic tests carried out for the oxidation of the azotartrazine colorant with $\mathrm{Al}-\mathrm{Fe}-\mathrm{PILC}$, the most efficient dose of $\mathrm{H}_{2} \mathrm{O}_{2}$ corresponds to 6 times the stoichiometric amount. With this dose, a decolorization greater than $98 \%$ and a TOC removal close to $52 \%$ is achieved. It is important to note that these results correspond to tests performed at $25^{\circ} \mathrm{C}$. It is well known that the mineralization of organic pollutants usually increases by elevating the temperature from 25 ${ }^{\circ} \mathrm{C}$ to around $80^{\circ} \mathrm{C}$. However, the CWPO process at elevated temperatures $\left(>40^{\circ} \mathrm{C}\right)$ will increase the total cost of the treatment and the thermal decomposition of $\mathrm{H}_{2} \mathrm{O}_{2}[20,63]$. 
For stability of the catalyst, the leached iron concentration was measured at the end of the oxidation tests. For all oxidation tests with $\mathrm{Ca}$ Bent and $\mathrm{Al}-\mathrm{Fe}-\mathrm{PILC}$, the leached iron concentration was less than $0.2 \mathrm{mg} / \mathrm{L}$. Thus, it can be concluded that only the heterogeneous Fenton reaction happened for the degradation of tartrazine. The low iron leaching indicated that the active phase of these catalysts is strongly fixed to the clay support and pillars, and that it is highly stable under oxidizing conditions of the reaction [34,64].

\section{Conclusions}

Pillared bentonite with $\mathrm{Al}-\mathrm{Fe}(\mathrm{Al}-\mathrm{Fe}-\mathrm{PILC})$ was effectively synthesized in a concentrated medium and used as heterogeneous Fenton-like catalyst in the oxidation of tartrazine azo-dye in an aqueous solution. Despite of the amount of iron incorporated into $\mathrm{Al}-\mathrm{Fe}$-PILC was very low compared to the iron content of Ca-Bent, its catalytic performance indicate that $\mathrm{Fe}$ incorporated by pillaring is more active than the purified clay.

The effect of $\mathrm{H}_{2} \mathrm{O}_{2}$ amount for tartrazine catalytic oxidation was evaluated. Increasing the dose of $\mathrm{H}_{2} \mathrm{O}_{2}(1,3$, and 6 times the required stoichiometric amount to completely oxidize the dye) increases decolorization and removal of TOC and TN. A high dose of $\mathrm{H}_{2} \mathrm{O}_{2}$ (9 times the required stoichiometric amount to completely oxidize the dye) does not improve the performance of the reaction.

The catalytic oxidation of tartrazine carried out with $\mathrm{Al}-\mathrm{Fe}-\mathrm{PILC}$ and 6 times the stoichiometric amount of $\mathrm{H}_{2} \mathrm{O}_{2}$ at $25{ }^{\circ} \mathrm{C}$, reached $98.2 \pm 1.8 \%$ of decolorization, $51.9 \pm 1.9 \%$ of TOC removal and $71.5 \pm 1.8 \%$ of TN conversion. Additionally, the leached iron concentration in all CWPO tests was less than $0.2 \mathrm{mg} / \mathrm{L}$, which guarantees the catalyst stability and that tartrazine oxidation occurred by a heterogeneous Fenton-like reaction.

\section{Acknowledgment}

The authors gratefully acknowledge the financial support of Universidad Nacional de Colombia Sede Manizales through the projects DIMA-UNAL (Code 38621 and 46078).

\section{References}

[1] Soon, A.N., Hameed, B.H. (2011). Heterogeneous catalytic treatment of synthetic dyes in aqueous media using Fenton and photoassisted Fenton process. Desalination, 269, 116, doi: 10.1016/j.desal.2010.11.002
[2] Zheng, Z., Levin, R.E., Pinkham, J.L., Shetty, K. (1999). Decolorization of polymeric dyes by a novel Penicillium isolate. Process Biochemistry, 34, 31-37, doi: 10.1016/S00329592(98)00061-2

[3] Koprivanac, N., Kušić, H. (2007). Chapter 5. AOPs as an Effective Tool for the Minimization of Hazardous Organic Pollutants in Colored Wastewater; Chemical and Photochemical Processes. In Lewinsky, A.A. (Editor) Hazardous Materials and Wastewater: Treatment, Removal and Analysis. New York: Nova Science Publishers, Inc.

[4] Zollinger, H. (2003). Color Chemistry. Synthesis, Properties and Applications of Organic Dyes and Pigments. Weinheim: Wiley VCH Publishers.

[5] Chang, J.-S., Chou, C., Lin, Y.-C., Lin, P.-J., Ho, J.-Y., Lee Hu, T. (2001). Kinetic characteristics of bacterial azo-dye decolorization by Pseudomonas luteola. Water Research, 35, 2841-2850, doi: 10.1016/S00431354(00)00581-9

[6] Saratale, R.G., Saratale, G.D., Chang, J.S., Govindwar, S.P. (2011). Bacterial decolorization and degradation of azo dyes: A review. Journal of the Taiwan Institute of Chemical Engineers, 42, 138-157, doi: 10.1016/j.jtice.2010.06.006

[7] Hou, H., Zhou, R., Wu, P., Wu, L. (2012). Removal of Congo red dye from aqueous solution with hydroxyapatite/chitosan composite. Chemical Engineering Journal, 211-212, 336-342, doi: 10.1016/j.cej.2012.09.100

[8] Khelifi, S., Ayari, F., Choukchou-Braham, A., Hassan Chehimi, D.B. (2018). The remarkable effect of $\mathrm{Al}-\mathrm{Fe}$ pillaring on the adsorption and catalytic activity of natural Tunisian bentonite in the degradation of azo dye. Journal of Porous Materials, 25, 885-896, doi: 10.1007/s10934-017-0500-4

[9] Gobara, M., Baraka, A. (2014). Tartrazine solution as dosimeter for gamma radiation measurement. International Letters of Chemistry, Physics and Astronomy, 14, 106-117, doi:10.18052/www.scipress.com/ILCPA.33.10 6

[10] Bastaki, M., Farrell, T., Bhusari, S., Pant, K., Kulkarni, R. (2017). Lack of genotoxicity in vivo for food color additive tartrazine. Food and Chemical Toxicology, 105, 278-284, doi: 10.1016/j.fct.2017.04.034

[11] Downham, A., Collins, P. (2000). Colouring our foods in the last and next millennium. Journal of Food Science and Technology, 35, 5-22, doi: 10.1046/j.1365-2621.2000.00373.x 
[12] Awaleh, M.O., Soubaneh, Y.D. (2014). Waste water treatment in chemical industries: The concept and current technologies. Hydrology: Current Research, 5, 1-12, doi: 10.4172/21577587.1000164

[13] Chung, K.-T. (1983). The significance of azoreduction in the mutagenesis and carcinogenesis of azo dyes. Mutation Research/Reviews in Genetic Toxicology, 114, 269-281, doi: 10.1016/0165-1110(83)90035-0

[14] Al-Degs, Y., Khraisheh, M.A.M., Allen, S.J., Ahmad, M.N.A. (2001). Sorption behavior of cationic and anionic dyes from aqueous solution on different types of activated carbons. Separation Science and Technology, 36, 91102, doi: 10.1081/SS-100000853

[15] Muhd Julkapli, N., Bagheri, S., Bee Abd Hamid, S. (2014). Recent advances in heterogeneous photocatalytic decolorization of synthetic dyes. The Scientific World Journal, 2014, 692307, doi: 10.1155/2014/692307

[16] Agustina, T.E. (2013). AOPs Application on Dyes Removal. In Sharma, S., Sanghi, R. (Editors) Wastewater Reuse and Management. Dordrecht: Springer.

[17] Atalay, S., Ersöz, G. (2015). Chapter 3. Advanced Oxidation Processes for Removal of Dyes from Aqueous Media. In Sharma, S.K. (Editor) Green Chemistry for Dyes Removal from Wastewater: Research Trends and Applications. Hoboken: John Wiley \& Sons, Inc.

[18] Glaze, W.H., Kang, J.-W., Chapin, D.H. (1987). The chemistry of water treatment processes involving ozone, hydrogen peroxide and ultraviolet radiation. Ozone: Science \& Engine ering, $\quad 9, \quad 335-352, \quad \mathrm{~d}$ o i : $10.1080 / 01919518708552148$

[19] Babuponnusami, A., Muthukumar, K. (2014). A review on Fenton and improvements to the Fenton process for wastewater treatment. Journal of Environmental Chemical Engineer$i n g, \quad 2, \quad 557-572, \quad \mathrm{~d}$ o i : 10.1016/j.jece.2013.10.011

[20] Tehrani-Bagha, A.R., Balchi, T. (2018). Chapter 12. Catalytic Wet Peroxide Oxidation. In Ameta, S.C., Ameta, R. (Editors) Advanced Oxidation Processes for Waste Water Treatment: Emerging Green Chemical Technology. London: Academic Press.

[21] Wang, N., Zheng, T., Zhang, G., Wang, P. (2016). A review on Fenton-like processes for organic wastewater treatment. Journal of Environmental Chemical Engineering, 4, 762787, doi: 10.1016/j.jece.2015.12.016

[22] Liotta, L.F., Gruttadauria, M., Di Carlo, G., Perrini, G., Librando, V. (2009). Heterogeneous catalytic degradation of phenolic sub- strates: Catalysts activity. Journal of Hazardous Materials, 162, 588-606, doi: 10.1016/j.jhazmat.2008.05.115

[23] Banković, P., Milutinović-Nikolić, A., Mojović, Z., Jović-Jovičić, N., Žunić, M., Dondur, V., Jovanović, D. (2012). Al,Fe-pillared clays in catalytic decolorization of aqueous tartrazine solutions. Applied Clay Science, 58, 73-78, doi: 10.1016/j.clay.2012.01.015

[24] Galeano, L.A., Gil, A., Vicente, M.A. (2010). Effect of the atomic active metal ratio in $\mathrm{Al} / \mathrm{Fe}-, \mathrm{Al} / \mathrm{Cu}-$ and $\mathrm{Al} /(\mathrm{Fe}-\mathrm{Cu})$-intercalating solutions on the physicochemical properties and catalytic activity of pillared clays in the CWPO of methyl orange. Applied Catalysis B: Environmental, 100, 271-281, doi: 10.1016/j.apcatb.2010.08.003

[25] Gao, H., Zhao, B.-X., Luo, J.-C., Wu, D., Ye, W., Wang, Q., Zhang, X.-L. (2014). Fe-Ni-Al pillared montmorillonite as a heterogeneous catalyst for the catalytic wet peroxide oxidation degradation of orange acid II: Preparation condition and properties study. $M i$ croporous and Mesoporous Materials, 196, $\begin{array}{llllllllll}2 & 0 & 8 & - & 2 & 1 & 5 & \mathrm{~d} & \mathrm{o} & \mathrm{i}\end{array}$ 10.1016/j.micromeso.2014.05.014

[26] Timofeeva, M.N., Khankhasaeva, S.T., Chesalov, Y.A., Tsybulya, S.V., Panchenko, V.N., Dashinamzhilova, E.T. (2009). Synthesis of Fe,Al-pillared clays starting from the Al,Fe-polymeric precursor: Effect of synthesis parameters on textural and catalytic properties. Applied Catalysis B: Environmental, 88, 127-134, doi: 10.1016/j.apcatb.2008.09.013

[27] Garrido-Ramírez, E.G., Theng, B.K.G., Mora, M.L. (2010). Clays and oxide minerals as catalysts and nanocatalysts in Fenton-like reactions - A review. Applied Clay Science, 47, 182-192, doi: 10.1016/j.clay.2009.11.044

[28] Leal, T.W., Lourenço, L.A., Brandão, H.d.L., da Silva, A., de Souza, S.M.A.G.U., de Souza, A.A.U. (2018). Low-cost iron-doped catalyst for phenol degradation by heterogeneous Fenton. Journal of Hazardous Materials, 359, 96-103, doi: 10.1016/j.jhazmat.2018.07.018

[29] Ribeiro, R.S., Silva, A.M.T., Figueiredo, J.L., Faria, J.L., Gomes, H.T. (2016). Catalytic wet peroxide oxidation: a route towards the application of hybrid magnetic carbon nanocomposites for the degradation of organic pollutants. A review. Applied Catalysis B: Environmental, $187,428-460$, doi: 10.1016/j.apcatb.2016.01.033

[30] Taran, O.P., Zagoruiko, A.N., Ayusheev, A.B., Yashnik, S.A., Prihod'ko, R.V., Ismagilov, Z.R., Goncharuk, V.V., Parmon, V.N. (2015). Wet peroxide oxidation of phenol over $\mathrm{Cu}$ ZSM-5 catalyst in a flow reactor. Kinetics and 
diffusion study. Chemical Engineering Journal, $282, \quad 108-115, \quad \mathrm{~d}$ o i : 10.1016/j.cej.2015.02.064

[31] Bertella, F., Pergher, S.B.C. (2015). Pillaring of bentonite clay with $\mathrm{Al}$ and Co. Microporous and Mesoporous Materials, 201, 116-123, doi: 10.1016/j.micromeso.2014.09.013

[32] Tatibouët, J.-M., Guélou, E., Fournier, J. (2005). Catalytic oxidation of phenol by hydrogen peroxide over a pillared clay containing iron. Active species and $\mathrm{pH}$ effect. Topics in Catalysis, 33, 225-232, doi: 10.1007/s11244005-2531-3

[33] Damardji, B., Khalaf, H., Duclaux, L., David, B. (2009). Preparation of $\mathrm{TiO}_{2}$-pillared montmorillonite as photocatalyst Part I. Microwave calcination, characterisation, and adsorption of a textile azo dye. Applied Clay Science, $44, \quad 201-205, \quad \mathrm{~d}$ o i : 10.1016/j.clay.2008.12.010

[34] Carriazo, J., Guélou, E., Barrault, J., Tatibouët, J.M., Molina, R., Moreno, S. (2005). Synthesis of pillared clays containing $\mathrm{Al}, \mathrm{Al}-$ $\mathrm{Fe}$ or Al-Ce-Fe from a bentonite: Characterization and catalytic activity. Catalysis Today, $107-108, \quad 126-132, \quad$ d o i : 10.1016/j.cattod.2005.07.157

[35] Sanabria, N.R., Centeno, M.A., Molina, R., Moreno, S. (2009). Pillared clays with Al-Fe and $\mathrm{Al}-\mathrm{Ce}-\mathrm{Fe}$ in concentrated medium: Synthesis and catalytic activity. Applied Catalysis A: General, 356, 243-249, doi: 10.1016/j.apcata.2009.01.013

[36] Sanabria, N.R., Molina, R., Moreno, S. (2009). Effect of ultrasound on the structural and textural properties of aAl-Fe pillared clays in a concentrated medium. Catalysis Letters, 130, 664-671, doi: 10.1007/s10562-009-9956-4

[37] Carriazo, J., Molina, R., Moreno, S. (2007). Structural and textural characterization of a Colombian bentonite. Revista Colombiana de Química, 36, 213-225.

[38] Day, P.R. (1965). Chapter 43. Particle fractionation and particle-size analysis. In Black, C.A., Evans, D.D., Ensminger, L.E., White, J.L., Clarck, F.E. (Editors) Methods of Soil Analysis, Part 1. Physical and Mineralogical Methods. Madison: American Society of Agronomy, Inc. Publisher.

[39] Macías-Quiroga, I.F., Giraldo-Gómez, G.I., Sanabria-González, N.R. (2018). Characterization of Colombian clay and its potential use as adsorbent. The Scientific World Journal, 2018, 1-11, doi: 10.1155/2018/5969178

[40] Gregg, S.J., Sing, K.S.W. (1982). Adsorption, Surface Area and Porosity. London: Academic Press.
[41] Herney-Ramirez, J., Lampinen, M., Vicente, M.A., Costa, C.A., Madeira, L.M. (2008). Experimental design to optimize the oxidation of Orange II dye solution using a clay-based Fenton-like catalyst. Industrial \& Engineering Chemistry Research, 47, 284-294, doi: 10.1021/ie070990y

[42] Ong, S.-A., Toorisaka, E., Hirata, M., Hano, T. (2005). Decolorization of azo dye (Orange II) in a sequential UASB-SBR system. Separation and Purification Technology, 42, 297302, doi: 10.1016/j.seppur.2004.09.004

[43] Carriazo, J.G., Guelou, E., Barrault, J., Tatibouët, J.M., Moreno, S. (2003). Catalytic wet peroxide oxidation of phenol over $\mathrm{Al}-\mathrm{Cu}$ or Al-Fe modified clays. Applied Clay Science, $22, \quad 303-308$, doi: 10.1016/S01691317(03)00124-8

[44] Barrault, J., Abdellaoui, M., Bouchoule, C., Majesté, A., Tatibouët, J.M., Louloudi, A., Papayannakos, N., Gangas, N.H. (2000). Catalytic wet peroxide oxidation over mixed (AlFe) pillared clays. Applied Catalysis B: Environmental, 27, L225-L230, doi: 10.1016/S0926-3373(00)00170-3

[45] Guélou, E., Barrault, J., Fournier, J., Tatibouët, J.-M. (2003). Active iron species in the catalytic wet peroxide oxidation of phenol over pillared clays containing iron. Applied Catalysis B: Environmental, 44, 1-8, doi: 10.1016/S0926-3373(03)00003-1

[46] Herney-Ramirez, J., Vicente, M.A., Madeira, L.M. (2010). Heterogeneous photo-Fenton oxidation with pillared clay-based catalysts for wastewater treatment: A review. Applied $\mathrm{Ca}$ talysis B: Environmental, 98, 10-26, doi: 10.1016/j.apcatb.2010.05.004

[47] Abou-Elela, S.I., Ali, M.E.M., Ibrahim, H.S. (2016). Combined treatment of retting flax wastewater using Fenton oxidation and granular activated carbon. Arabian Journal of Chemistry, 9, 511-517, doi: 10.1016/j.arabjc.2014.01.010

[48] Sivrikaya, O., Uzal, B., Ozturk, Y.E. (2017). Practical charts to identify the predominant clay mineral based on oxide composition of clayey soils. Applied Clay Science, 135, 532537, doi: 10.1016/j.clay.2016.09.035

[49] Occelli, M.L., Bertrand, J.A., Gould, S.A.C., Dominguez, J.M. (2000). Physicochemical characterization of a Texas montmorillonite pillared with polyoxocations of aluminum: Part I: the microporous structure. $\mathrm{Mi}$ croporous and Mesoporous Materials, 34, 195-206, doi: 10.1016/S1387-1811(99)00173-0

[50] Occelli, M.L., Auroux, A., Ray, G.J. (2000). Physicochemical characterization of a Texas montmorillonite pillared with polyoxocations of aluminum. II. NMR and microcalorimetry 
results. Microporous and Mesoporous Materials, 39, 43-56, doi: 10.1016/S13871811(00)00175-X

[51] Thommes, M., Kaneko, K., Neimark, A.V., Olivier, J.P., Rodriguez-Reinoso, F., Rouquerol, J., Sing, K.S.W. (2015). Physisorption of gases, with special reference to the evaluation of surface area and pore size distribution (IUPAC Technical Report). Pure and Applied Chemistry, 87, 1051-1069, doi: 10.1515/pac2014-1117

[52] Depci, T., Çelik, M.S. (2015). Chapter 9. Dye Adsorption on Expanding Three-Layer Clays. In Sharma, S.K. (Ed.) Green Chemistry for Dyes Removal from Wastewater. Salem: Scrivener Publishing LLC.

[53] Zohra, B., Aicha, K., Fatima, S., Nourredine, B., Zoubir, D. (2008). Adsorption of direct red 2 on bentonite modified by cetyltrimethylammonium bromide. Chemical Engineering Journal, 136, 295-305, doi: 10.1016/j.cej.2007.03.086

[54] Marco-Brown, J.L., Barbosa-Lema, C.M., Torres Sánchez, R.M., Mercader, R.C., dos Santos Afonso, M. (2012). Adsorption of picloram herbicide on iron oxide pillared montmorillonite. Applied Clay Science, 58, 25-33, doi: 10.1016/j.clay.2012.01.004

[55] Aguiar, J.E., Bezerra, B.T.C., Siqueira, A.C.A., Barrera, D., Sapag, K., Azevedo, D.C.S., Lucena, S.M.P., Silva, I.J. (2014). Improvement in the adsorption of anionic and cationic dyes from aqueous solutions: A comparative study using aluminium pillared clays and activated carbon. Separation Science and Technology, 49, 741-751, doi: 10.1080/01496395.2013.862720

[56] Inchaurrondo, N.S., Massa, P., Fenoglio, R., Font, J., Haure, P. (2012). Efficient catalytic wet peroxide oxidation of phenol at moderate temperature using a high-load supported copper catalyst. Chemical Engineering Journal, $198-199, \quad 426-434, \quad \mathrm{~d}$ o i : 10.1016/j.cej.2012.05.103

[57] Chen, Q., Wu, P., Li, Y., Zhu, N., Dang, Z. (2009). Heterogeneous photo-Fenton photodegradation of reactive brilliant orange X-GN over iron-pillared montmorillonite under visible irradiation. Journal of Hazardous Materials, $168, \quad 901-908, \quad \mathrm{~d}$ o i : 10.1016/j.jhazmat.2009.02.107
[58] Bobu, M., Yediler, A., Siminiceanu, I., Schulte-Hostede, S. (2008). Degradation studies of ciprofloxacin on a pillared iron catalyst. Applied Catalysis B: Environmental, 83, 1523, doi: 10.1016/j.apcatb.2008.01.029

[59] Ramirez, J.H., Costa, C.A., Madeira, L.M., Mata, G., Vicente, M.A., Rojas-Cervantes, M.L., López-Peinado, A.J., Martín-Aranda, R.M. (2007). Fenton-like oxidation of Orange II solutions using heterogeneous catalysts based on saponite clay. Applied Catalysis B: Environmental, 71, 44-56, doi: 10.1016/j.apcatb.2006.08.012

[60] Dutta, K., Mukhopadhyay, S., Bhattacharjee, S., Chaudhuri, B. (2001). Chemical oxidation of methylene blue using a Fenton-like reaction. Journal of Hazardous Materials, 84, 5771, doi: 10.1016/S0304-3894(01)00202-3

[61] Guedes, A.M.F.M., Madeira, L.M.P., Boaventura, R.A.R., Costa, C.A.V. (2003). Fenton oxidation of cork cooking wastewater - overall kinetic analysis. Water Research, 37, 30613069, doi: 10.1016/S0043-1354(03)00178-7

[62] Thiam, A., Zhou, M., Brillas, E., Sirés, I. (2014). Two-step mineralization of Tartrazine solutions: Study of parameters and byproducts during the coupling of electrocoagulation with electrochemical advanced oxidation processes. Applied Catalysis B: Environmental, 150-151, 116-125, doi: 10.1016/j.apcatb.2013.12.011

[63] Yan, Y., Wu, X., Zhang, H. (2016). Catalytic wet peroxide oxidation of phenol over $\mathrm{Fe}_{2} \mathrm{O}_{3} / \mathrm{MCM}-41$ in a fixed bed reactor. Separation and Purification Technology, 171, 52-61, doi: 10.1016/j.seppur.2016.06.047

[64] Sanabria, N.R., Molina, R., Moreno, S. (2012). Development of pillared clays for wet hydrogen peroxide oxidation of phenol and its application in the posttreatment of coffee wastewater. International Journal of Photoenergy, $2012, \quad 864104, \quad \mathrm{doi}$ : $10.1155 / 2012 / 864104$ 